\title{
Structure and Morphology of Cellulose Films Coagulated from Novel Cellulose/Aqueous Sodium Hydroxide Solutions by Using Aqueous Sulfuric Acid with Various Concentrations
}

\author{
Toshihiko Matsui, Takako Sano, Chihiro Yamane, Kenji Kamide,* \\ and Kunihiko OKAJIMA \\ Fundamental Research Laboratory of Natural and Synthetic Polymers, \\ Asahi Chemical Industry Co., Ltd., \\ 11-7 Hacchownawate, Takatsuki, Osaka 569, Japan \\ * Laboratory of Clothing, Faculty of Education, Kumamoto University, \\ Kurokami 2-40-1, Kumamoto 860, Japan
}

(Received January 9, 1995)

\begin{abstract}
Structure and morphology of the cellulose films coagulated from novel cellulose $/ 9 \mathrm{wt} \%$ aqueous (aq.) sodium hydroxide $(\mathrm{NaOH})$ systems (polymer concentration $\left.C_{\mathrm{P}} \leqq 5.6 \mathrm{wt} \%\right)$ by using aq. sulfuric acid $\left(\mathrm{H}_{2} \mathrm{SO}_{4}\right)$ with various concentration $\left(C_{\mathrm{sa}}=20-80 \mathrm{wt} \%\right)$ as coagulants were investigated. For this purpose two types of alkali-soluble celluloses with either crystal form of cellulose-I (Cell-I; steam exploded spruce pulp) or cellulose-II (Cell-II; regenerated from cotton/cuprammonium solution) were utilized. SEM observation on the lyophilized coagulated cellulose films revealed that all the films have basically porous structure more or less, constituted by collision of secondary particles. Coagulation from two types of cellulose solutions underwent in a quite different way as a function of $C_{\mathrm{sa}}$ of coagulant: (1) For alkali-soluble Cell-II system, the existence of secondary particles was evident in the range of $C_{\mathrm{sa}} \geqq 20 \mathrm{wt} \%$ and the most dense structure was given when $C_{\mathrm{sa}}=60-65 \mathrm{wt} \%$, (2) For alkali-soluble Cell-I system, the secondary particles became detectable at $C_{\mathrm{sa}} \geqq 40 \mathrm{wt} \%$ and the coagulant with $C_{\mathrm{sa}}=70 \mathrm{wt} \%$ gave the most dense structure of the film, and (3) the size of particles constituting the most dense films is smaller for Cell-II system than Cell-I system. The coagulant with $C_{\mathrm{sa}} \geqq 60 \mathrm{wt} \%$ proved to act as strong dehydrant from cellulose solutions by Raman spectroscopy and the neutralization rate of Cell-II system was much higher than Cell-I system. CP/MAS ${ }^{13} \mathrm{C}$ NMR analysis showed that both densely coagulated films developed practically no intramolecular hydrogen bond at $\mathrm{C}_{3}$ position.

KEY WORDS Alkali-Soluble Cellulose / Coagulated Cellulose Film / SEM

Observation / CP/MAS ${ }^{13} \mathrm{C}$ NMR / Raman Spectroscopy /
\end{abstract}

Kamide and his coworkers ${ }^{1-4}$ have already succeeded in preparing the completely soluble cellulose samples with crystal forms of either cellulose-I (Cell-I) or cellulose-II (Cell-II) into $8-10 \mathrm{wt} \%$ aqueous (aq.) sodium hydroxide $(\mathrm{NaOH})$ solution at low temperatures. The alkali-soluble Cell-I was prepared by simple physical treatment (so-called steam-explosion) on spruce pulp under definite conditions ${ }^{1-3}$ and the alkali-soluble Cell-II was regenerated from cellulose (cotton linter)/cuprammonium solution by specialized coagulation condition. ${ }^{4}$
The degree of break-down in intramolecular hydrogen bonds at $\mathrm{C}_{3}$ or $\mathrm{C}_{3}+\mathrm{C}_{6}$ positions $\left(\chi_{\mathrm{am}}\left(\mathrm{C}_{3}\right)\right.$ or $\left.\chi_{\mathrm{am}}\left(\mathrm{C}_{3}+\mathrm{C}_{6}\right)\right)$, estimated by $\mathrm{CP} /$ MAS ${ }^{13} \mathrm{C}$ NMR analysis,was affirmed to govern the solubility of Cell-I and Cell-II into ca. $9 \mathrm{wt} \%$ aq. $\mathrm{NaOH}^{3-5}$. The above research group made considerable effort to clarify the natures of the above novel cellulose/aq. $\mathrm{NaOH}$ (alkali) solution system ${ }^{6-10}$ : (1) Aq. $\mathrm{NaOH}$ solution which can dissolve these alkali-soluble celluloses proved to take a specific solvation of water molecules on sodium $\left(\mathrm{Na}^{+}\right)$and 
hydroxyl $\left(\mathrm{OH}^{-}\right)$ions, ${ }^{6}(2)$ in the alkali-soluble cellulose/aq. $\mathrm{NaOH}$ and the alkali-soluble cellulose/aq. lithium hydroxide systems cellulose was dissolved molecularly without forming a derivative or complex, ${ }^{7,8}$ (3) the alkalisoluble celluloses were dissolved in aq. $\mathrm{NaOH}$ with specific concentrations without forming so-called alkali-celluloses during its dissolution. ${ }^{9,10}$

With those basic knowledges, Yamashiki et $a l .{ }^{11,12}$ carried out preliminary wet-spinning experiments on the alkali-soluble Cell-I/aq. $\mathrm{NaOH}$ solution using a $20 \mathrm{wt} \%$ aq. $\mathrm{H}_{2} \mathrm{SO}_{4}$ as a coagulant, obtaining a quite porous cellulose fiber with cellulose II crystal which has low degree of break-down of intramolecular hydrogen bond at $\mathrm{C}_{3}\left(\chi_{\mathrm{am}}\left(\mathrm{C}_{3}\right)\right)$ and in which cellulose molecules are quite mobile when wet. The study was still premature and not systematical but if the above new process to produce a new cellulose fiber was established it will give a paramount impact on the present regenerated cellulose fiber industry because the new process has potential possibility to overcome the vital environmental problems of waste (sometime toxic) gases and heavy metal, which the present regenerated cellulose fiber industry (viscose rayon and cuprammonium rayon) encounters.

To meet the above environmental problems, many organic solvent systems such as dimethylformamide (DMF)/nitrogen oxide, ${ }^{13}$ $N$-methyl-morpholine $N$-oxide(NMMO)/ water, ${ }^{14}$ dimethylsulfoxide/paraformaldehyde, ${ }^{15}$ liquid ammonia/ammonium thiocyanate/water, ${ }^{16}$ chloral/DMF/pyridine ${ }^{17}$ and dimethylacetamide/lithium chloride ${ }^{18}$ systems aiming at a closed process for the regenerated fiber production have been investigated. Although.an industrial spinning system has been developed using NMMO/water as cellulose solvent, most of the systems seem to be yet unsuccessful from industrial view point, partly because of the high toxicity of solvent itself, the production of the explosive byproducts and the difficulty in solvent recovery. ${ }^{19}$ In this connection, NMMO/water system is not an exception. In addition, with some exceptions in most of these organic solvents as well as in viscose and cuprammonium cellulose solutions cellulose dissolves as a derivative or complex, requiring the chemical regenerating process besides neutralization and refining processes when these systems are employed to produce the regenerated cellulose fiber.

This situation creates an interesting and important research field, that is, the utilization of the novel cellulose/aq. alkali solution, which seems not to bring about any serious hazards and requires no chemical regeneration process in producing fibers, films and so on. In the case of wet-spinning, selection of coagulant for the polymer solution in question is said to be thermodynamically most influential on the properties of final products. ${ }^{20}$ Concerning the present cellulose solutions, Kamide and his coworkers $^{21,22}$ reported that alkali-soluble Cell-I and Cell-II solution systems exhibited quite different flow properties and gelation phenomena. This indicated that the products coagulated from the above two solution systems might have different characteristics owing to different coagulation phenomena.

In this paper, an attempt was systematically made to clarify the difference in structure and morphology of the cellulose films coagulated from the above two solutions by using sulfuric acid with various concentration, as a fundamental basis to establish an appropriate wet spinning method for these novel cellulose solutions.

\section{EXPERIMENTAL}

\section{Alkali Soluble Cellulose Samples}

An alkali soluble Cell-I sample (the viscosityaverage degree of polymerization $P_{\mathrm{v}}=331$, $\chi_{\mathrm{am}}\left(\mathrm{C}_{3}\right)=46 \%$, solubility $S_{\mathrm{a}}=c a .100 \%$ ) was prepared by applying the steam explosion treatment on a soft wood (mainly white spruce) pulp (Alaska pulp (U.S.A.), manufactured by Alaska Pulp Co.: $\alpha$-cellulose content; $90.1 \mathrm{wt} \%$, 
$\left.P_{\mathrm{v}}=1060\right)$ under the conditions of water vapor pressure $P=2.9 \mathrm{MPa}$ and the treating time $t=30 \mathrm{~s}$ with water content of the original cellulose of $80 \%$, as described in the previous papers. ${ }^{1-3}$ An alkali soluble Cell-II sample $\left(P_{\mathrm{v}}=453, \chi_{\mathrm{am}}\left(\mathrm{C}_{3}\right)=92 \%, S_{\mathrm{a}}=100 \%\right)$ was prepared as follows: A purified cotton linter $(\alpha-$ cellulose content; $\left.95.7 \%, P_{\mathrm{v}}=1279\right)$ was dissolved in a cuprammonium solution $\left(\mathrm{NH}_{3} / \mathrm{Cu} /\right.$ $\mathrm{H}_{2} \mathrm{O}=7.0 / 3.6 / 89.4$, w/w/w) at polymer concentration of $8 \mathrm{wt} \%$. The solution was poured into acetone and the resultant precipitates were regenerated by $2 \mathrm{wt} \%$ aq. $\mathrm{H}_{2} \mathrm{SO}_{4}$ for $3 \mathrm{~h}$, followed by neutralization, washing and drying. Here, $P_{\mathrm{v}}$ and $S_{\mathrm{a}}$ were estimated by the methods described in the previous papers. ${ }^{1-3} \chi_{\mathrm{am}}\left(\mathrm{C}_{3}\right)$ was estimated by the method described later.

\section{Preparation of Cellulose/aq. Alkali Solutions}

The given amounts of the alkali-soluble cellulose (water content about 8-12 wt \%) was dispersed into $8.65 \mathrm{wt} \%$ aq. $\mathrm{NaOH}$ solution, precooled at $4^{\circ} \mathrm{C}$, stood for $8 \mathrm{~h}$ with intermittently mixing by a home mixer (Type SM, Sanyo Electric Co., Ltd., Japan) to give polymer concentration $C_{\mathrm{P}}=3.4-5.6 \mathrm{wt} \%$ and the resultant solution was subjected to centrifugation (55P Type centrifugal apparatus, Hitachi Machinary Co., Ltd., Japan) at $10000 \mathrm{rpm}$ for $60 \mathrm{~min}$ in order to exclude the slightly remaining undissolved part and to carry out the degasification at $4^{\circ} \mathrm{C}$. The solution thus obtained was immediately subjected to film preparation by wet-coagulation method.

\section{Preparation of Coagulated Films}

Cellulose solutions $\left(C_{\mathrm{P}}=3.4-5.6 \mathrm{wt} \%\right)$ was cast on a glass plate $(10 \mathrm{~cm} \times 10 \mathrm{~cm})$ to thickness of $1 \mathrm{~mm}$ and the glass plate was immersed gently to aq. $\mathrm{H}_{2} \mathrm{SO}_{4}$ solutions (concentration $C_{\mathrm{sa}}=20-80 \mathrm{wt} \%$ ) controlled at $-6-40^{\circ} \mathrm{C}$ for $1-30 \mathrm{~min}$. The coagulated films were washed thoroughly with water for sufficient time at $20^{\circ} \mathrm{C}$ and the resultant wet gel films were wrapped in aluminium foil, followed by freezing in liquid nitrogen. The frozen films were lyophilized with an apparatus (Type FD-1, Tokyo Rika Machinery Co., Ltd., Japan). The gel films coagulated with $C_{\mathrm{sa}}=80 \mathrm{wt} \%$ could not be recovered owing to strong dissolving action of the coagulant against the coagulated films.

\section{Scanning Electron Microscopic (SEM) Ob- servation}

The cracked face of the lyophilized film samples were sputtered with gold by using a metal evaporating apparatus (Fine coat ion sputter JFC-1100, JEOL Ltd., Japan) under $1.2 \mathrm{kV}$ and $5 \mathrm{~mA}$ for $6 \mathrm{~min}$ and the sputtered samples were observed on a field emission type scanning electron microscope (S-800 type field emission scanning electron microscope, $\mathrm{Hi}$ tachi, Japan) at an accelerating voltage of 10 $\mathrm{kV}$ with observation magnification of 5000 30000 and photographed by a Polaroid camera. Average pore size $(2 r)$ observed for the surface (contact face to coagulant, $c a$. $50 \mathrm{~nm}$ in thickness) and inner phase of the lyophilized films ( $c a .500 \mathrm{~nm}$ thick) was estimated and used as a measure for coagulation state of the films to examine the relation between the $2 r$ and coagulation conditions.

\section{Volume Contraction of Cellulose/aq. $\mathrm{NaOH}$ Solution in Coagulant}

A 100 gram $(\mathrm{g})$ of cellulose solution $\left(C_{\mathrm{P}}=\right.$ $4.1 \mathrm{wt} \%$ for Cell-I solution system, $C_{\mathrm{P}}=4.7$ $\mathrm{wt} \%$ for Cell-II solution system; initial volume $V_{0}=8.85 \mathrm{~cm}^{3}$ ) precooled at $4^{\circ} \mathrm{C}$ was placed in a $30 \mathrm{ml}$ vial and an aq. $\mathrm{H}_{2} \mathrm{SO}_{4}$ solution with $C_{\text {sa }}=20-80 \mathrm{wt} \%$ was poured calmly and stood for $24 \mathrm{~h}$ at $4^{\circ} \mathrm{C}$. From the coagulated polymer phase an excessive sulfuric acid was washed with water, neutralized with a dilute aq. sodium hydrogen carbonate $\left(\mathrm{NaHCO}_{3}\right)$ solution, washed again by water and finally an excessive water was absorbed away with tissue paper. The resultant polymer phase was put into a flask containing water and the increased volume $(V)$ was measured. $V / V_{0}$ was defined as volume contraction to express the coagula- 
tion ability of the aq. $\mathrm{H}_{2} \mathrm{SO}_{4}$ solutions employed.

\section{Raman Spectroscopy}

Raman spectra for aq. $\mathrm{H}_{2} \mathrm{SO}_{4}$ with various $C_{\text {sa }}$ and aq. sodium sulfate $\left(\mathrm{Na}_{2} \mathrm{SO}_{4}\right)$ solution controlled at $5^{\circ} \mathrm{C}$ were recorded on an Argon Laser Raman spectrophotometer (JRS-400, JEOL Ltd., Japan). In order to clarify the material transportation between aq. $\mathrm{H}_{2} \mathrm{SO}_{4}$ with $C_{\mathrm{sa}}=70 \mathrm{wt} \%$ and $8.65 \mathrm{wt} \%$ aq. $\mathrm{NaOH}$ or alkali-soluble cellulose $/ 8.65 \mathrm{wt} \%$ aq. $\mathrm{NaOH}$ solutions the following procedure was adopted: A Teflon porous membrane with diameter of $3 \mathrm{~cm}$ (pore size; $0.45 \mu \mathrm{m}$, Sumitomo Denko Co., Ltd., Japan) was placed steadily between two glass cells and the whole apparatus was controlled at $5^{\circ} \mathrm{C}$. The Teflon membrane was in advance dipped into acetone and acetone was substituted by acetone-water $(1: 1, \mathrm{v} / \mathrm{v})$ mixture, water and $8.65 \mathrm{wt} \%$ aq. $\mathrm{NaOH}$ solution in this order. Into the two glass cells an aq. $\mathrm{H}_{2} \mathrm{SO}_{4}$ with $C_{\mathrm{sa}}=70 \mathrm{wt} \%$ and $8.65 \mathrm{wt} \%$ aq. $\mathrm{NaOH}$ or the above-mentioned cellulose solutions were placed, respectively (see Figure 1). For the former case, sampling was made from interfacial parts of both cells separated by Teflon membrane. In the latter case, sampling was made only from the interfacial part of the aq. $\mathrm{H}_{2} \mathrm{SO}_{4}$ solution side as a function of elapsed time from the instance of contact of two solutions. The measuring conditions are as follows: Raman shift range,

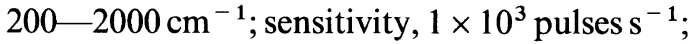
time constant, $1 \times 3.2 \mathrm{~s}$; irradiation wave length, $5145 \mathrm{~A}$; source voltage, $110 \mathrm{~mW}$.

\section{Neutralization Rate}

Each $10 \mathrm{ml}$ of aq. $\mathrm{H}_{2} \mathrm{SO}_{4}$ solution with $C_{\mathrm{sa}}=20-80 \mathrm{wt} \%$ was put into a test tube (inner volume, $20 \mathrm{ml}$ ) and onto it alkali-soluble Cell-I or Cell-II solution with $C_{\mathbf{P}}=c a$. $5 \mathrm{wt} \%$ containing thymol blue as a neutralization indicator was poured gently. The distance $(L)$ from the boundary between aq. $\mathrm{H}_{2} \mathrm{SO}_{4}$ and polymer solution was measured as a function

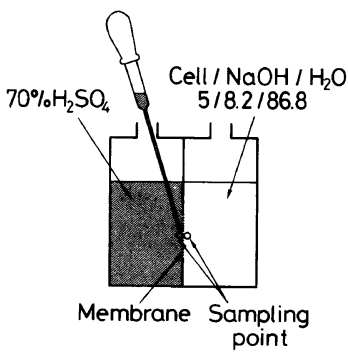

Figure 1. An experimental apparatus for material transportation between aq. $\mathrm{H}_{2} \mathrm{SO}_{4}$ solution and aq. $\mathrm{NaOH}$ solution or cellulose/aq. $\mathrm{NaOH}$ system for sampling of Raman spectroscopy.

of time by noticing the boundary front where the color of the indicator changed.

\section{Solid-State CP/MAS ${ }^{13}$ C NMR Measurement}

$\mathrm{CP} / \mathrm{MAS}{ }^{13} \mathrm{C}$ NMR spectra of the lyophilized coagulated films obtained here were recorded both at dry and wet states on a Fourier transform (FT) NMR spectrometer (FX-200, JEOL Ltd., Japan) under the following operating conditions: $50.1 \mathrm{MHz}$ for ${ }^{13} \mathrm{C}$ nucleus; data points, 8192 (4096 zero-filling); accumulation, 2000-3000; pulse width, $5.5 \mu \mathrm{s}$; contact time, $2 \mathrm{~ms}$; pulse interval, $5.1 \mathrm{~s}$; spectral width, $20000 \mathrm{~Hz}$; acquisition time, $102.4 \mathrm{~ms}$. From the spectra the degree of break-down of the intramolecular hydrogen bond at $\mathrm{C}_{3^{-}}$ hydroxyl groups in glucopyranose unit, $\chi_{\mathrm{am}}\left(\mathrm{C}_{3}\right)$ was estimated by the following equations proposed in our previous work ${ }^{1-4}$ :

$$
\chi_{\mathrm{am}}\left(\mathrm{C}_{3}\right)=100 \times I_{\mathrm{h}}\left(\mathrm{C}_{4}\right) /\left\{I_{\mathrm{h}}\left(\mathrm{C}_{4}\right)+I_{1}\left(\mathrm{C}_{4}\right)\right\}
$$

The ratio of the value at dry and wet states $\Delta \chi\left(=\chi_{\mathrm{am}}\left(\mathrm{C}_{3}\right)\right.$ wet $/ \chi_{\mathrm{am}}\left(\mathrm{C}_{3}\right)$ dry $)$ was also calculated, as a measure of molecular mobility in the films when wet.

\section{RESULTS AND DISCUSSION}

\section{Influence of Concentration of Coagulant on the Coagulation State of the Films}

Figure 2 shows SEM micrographs of surface and inner phase of the lyophilized film (A, 
(A)

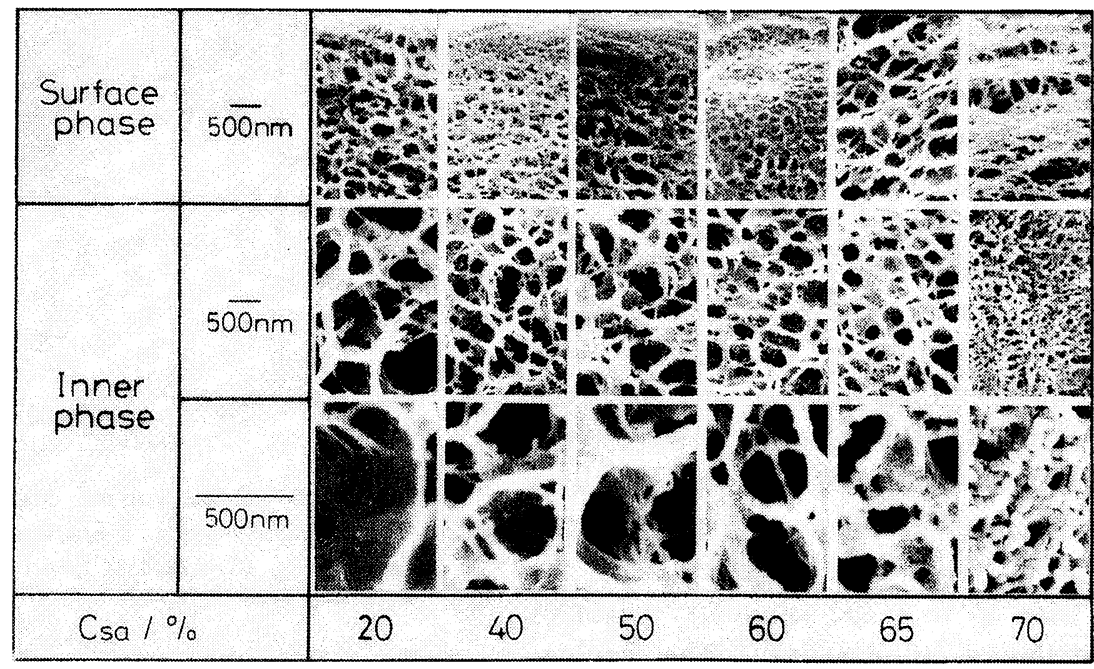

(B)

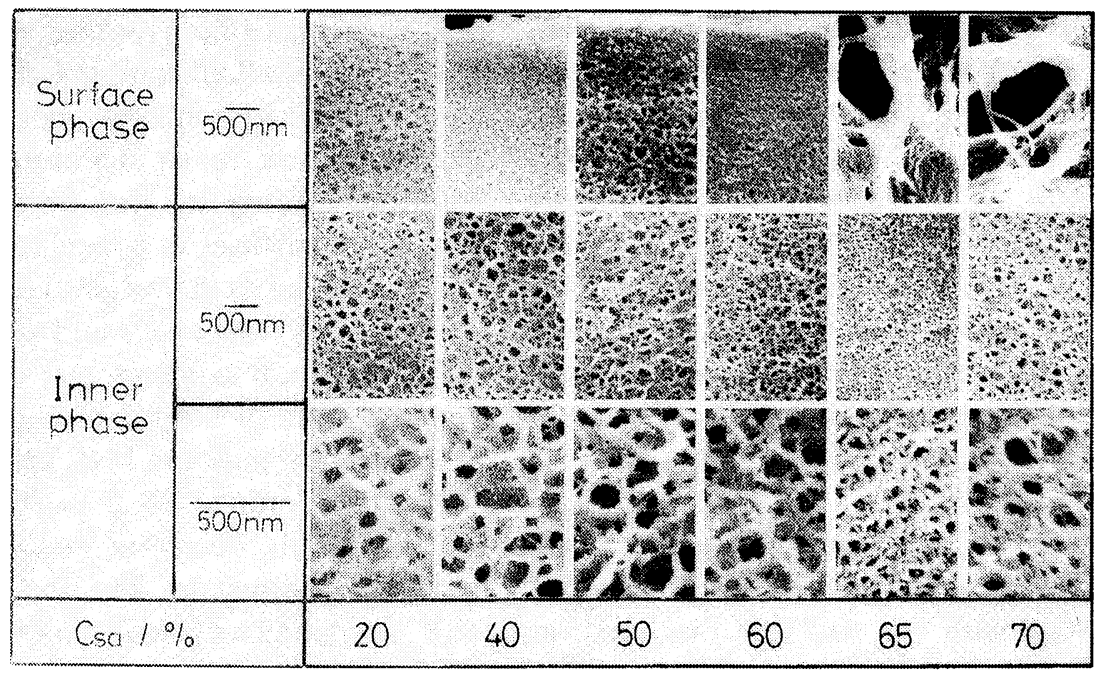

Figure 2. SEM micrographs of surface and inner phase of the lyophilized films coagulated by aq. $\mathrm{H}_{2} \mathrm{SO}_{4}$ with concentration $C_{\mathrm{sa}}=20-70 \mathrm{wt} \%$ at $5^{\circ} \mathrm{C}$ for $5 \mathrm{~min}$ : A, Cell-I $\left(C_{\mathrm{P}}=4.1 \mathrm{wt} \%\right)$ system; B, Cell-II $\left(C_{\mathrm{P}}=4.7 \mathrm{wt} \%\right)$ system. For the inner phase, a magnified $(\times 30000)$ SEM micrographs are also shown.

Cell-I $\left(C_{\mathrm{P}}=4.1 \mathrm{wt} \%\right)$ system; $\mathrm{B}$, Cell-II $\left(C_{\mathrm{P}}=\right.$ $4.7 \mathrm{wt} \%$ ) system) coagulated by aq. $\mathrm{H}_{2} \mathrm{SO}_{4}$ with $C_{\mathrm{sa}}=20-70 \mathrm{wt} \%$ at $5^{\circ} \mathrm{C}$ for $5 \mathrm{~min}$. For the inner phase, a magnified $(\times 30000)$ SEM micrographs are also shown. Average pore size $(2 r)$ of the films obtained from Cell-I system (hereafter denoted simply as Cell-I film(s)) seems smaller for the surface than the inner phase but not showing a clear skin structure.
Contrarily, the films obtained from Cell-II system (hereafter denoted as Cell-II film(s)) exhibited the clear skin structure (thickness, $0.5-1.5 \mu \mathrm{m}$, as shown by the mark $\Leftrightarrow ; 2 r$, $\sim 0 \mathrm{~nm}$ ) when aq. $\mathrm{H}_{2} \mathrm{SO}_{4}$ solutions with $C_{\mathrm{sa}}=40-60 \mathrm{wt} \%$ were used as coagulant but aq. $\mathrm{H}_{2} \mathrm{SO}_{4}$ with $C_{\mathrm{sa}} \geqq 65 \mathrm{wt} \%$ gave somewhat porous and denaturated surface probably due to the strong dissolving action of the coagulant 
against the films.

The inner phase of Cell-I films coagulated by aq. $\mathrm{H}_{2} \mathrm{SO}_{4}$ with $C_{\mathrm{sa}}=20-65 \mathrm{wt} \%$ seems to be basically composed of the back-bone structure is accompanied with very thin membrane, as shown by the arrow, which has defects (pore with diameter of $20-100 \mathrm{~nm}$ ) (this structure is hereafter denoted as $\mathrm{UP}+\mathrm{M}$ structure). According to Kamide and his coworkers, ${ }^{20,23}$ the mechanism of membrane formation from polymer solution by solvent casting method is that the primary particles with diameter of $10-30 \mathrm{~nm}$ generate at the early stage of phase separation and with the lapse of time grow to the secondary particles with diameter of $50-600 \mathrm{~nm} .^{24}$ The amalgamation of the secondary particles brings about the porous polymeric membrane. So the network like back-bone structure indicated here is throught to be made by collision of the second particles (diameter $d_{\mathrm{P}}=c a .50 \mathrm{~nm}$ ). Aq. $\mathrm{H}_{2} \mathrm{SO}_{4}$ with $C_{\mathrm{sa}}=70 \mathrm{wt} \%$ gave undoubtedly uncircular pore (UP) ${ }^{20}$ structure made by the collision of secondary particles with $d_{\mathrm{P}}=20$ $100 \mathrm{~nm}$. The average pore size $(2 r)$ of the inner phase of Cell-I films is summarized as a function of $C_{\mathrm{sa}}$ as follows: $2 r=c a .1000 \mathrm{~nm}$ at $C_{\mathrm{sa}}=20 \mathrm{wt} \%, 2 r=c a .500 \mathrm{~nm}$ at $C_{\mathrm{sa}}=40-65$ wt \%, $2 r=c a .100 \mathrm{~nm}$ at $C_{\mathrm{sa}}=70 \mathrm{wt} \%$. Note that a clear secondary particles with $d_{\mathrm{P}}=c a$. $40 \mathrm{~nm}$ was first observed for Cell-I films when aq. $\mathrm{H}_{2} \mathrm{SO}_{4}$ with $C_{\mathrm{sa}}=65 \mathrm{wt} \%$ is used as coagulant and that the thin membrane accompanying the back-bone structure disappeared at $C_{\mathrm{sa}}=70 \mathrm{wt} \%$. For Cell-II solution system, all aq. $\mathrm{H}_{2} \mathrm{SO}_{4}$ solution employed here gave the UP structure to Cell-II films with far smaller pore size than that for Cell-I, compared at the same $C_{\text {sa }}$ level. With an increase in $C_{\text {sa }}, 2 r$ of inner phase of Cell-II films is almost independent of $C_{\text {sa }}$, except for that of $C_{\mathrm{sa}}=65 \%$, which exhibits a smaller pore size $(c a .50 \mathrm{~nm})$. The secondary particle size $\left(d_{\mathrm{p}}\right)$ never grows larger beyond $30 \mathrm{~nm}$. The considerable difference in coagulation state observed for Cell-I and Cell-II films might closely relate to their

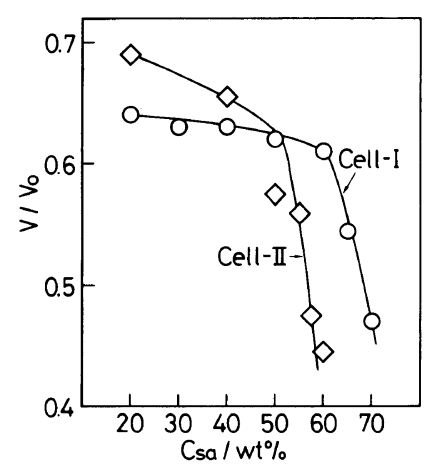

Figure 3. Plots of the volume contraction $V / V_{0}$ of cellulose solution systems as a function of concentration of coagulant $C_{\mathrm{sa}}: O$, Cell-I $\left(C_{\mathrm{P}}=4.1 \mathrm{wt} \%\right) ; \diamond$, Cell-II $\left(C_{\mathrm{P}}=4.7 \mathrm{wt} \%\right)$.

dissolved state in aq. $\mathrm{NaOH}$ solution.

One of plausible hypotheses may reside in that a part of alkali-soluble Cell-I intrinsically associates with each other constituting some fixed structure in its dissolved state in the solution, leading to very porous and larger secondary particles in coagulation process.

Figure 3 shows the volume contraction $V / V_{0}$ of Cell-I $\left(C_{\mathrm{P}}=4.1 \mathrm{wt} \%\right)$ and Cell-II $\left(C_{\mathrm{P}}=4.7\right.$ wt $\%$ ) solution systems as a function of concentration of coagulant $C_{\mathrm{sa}}$. Cell-I system revealed no significant $V / V_{0}$ change $(=0.64$ 0.61 ) in the range of $C_{\mathrm{sa}}=20-60 \mathrm{wt} \%$ but $V / V_{0}$ abruptly decreased to 0.47 at $C_{\mathrm{sa}}=70$ $\mathrm{wt} \%$. In contrast to this, for Cell-II system $V / V_{0}$ decreased with an increase in $C_{\mathrm{sa}}$ showing relatively sharp decrease in the range of $C_{\mathrm{sa}}=$ $50-60 \mathrm{wt} \%$, and the evaluation of $V / V_{0}$ at $C_{\mathrm{sa}}=70 \mathrm{wt} \%$ became impossible because of the dissolution of the polymer phase by the coagulant. These facts closely correspond to the coagulation state observed in Figure 2. For both systems, aq. $\mathrm{H}_{2} \mathrm{SO}_{4}$ solutions with specific $C_{\text {sa }}(=70 \mathrm{wt} \%$ for Cell-I, $60 \mathrm{wt} \%$ for Cell-II) have an ability to give a dense coagulation state of Cell-I and Cell-II films.

Figure 4 shows typical Raman spectra of aq. $\mathrm{H}_{2} \mathrm{SO}_{4}$ solutions $\left(C_{\mathrm{sa}}=97 \mathrm{wt} \%\right.$ and 60 $\mathrm{wt} \%$ ). Several characteristic peaks corresponding to non-dissociated $\mathrm{H}_{2} \mathrm{SO}_{4}\left(\mathrm{a}, 1374 \mathrm{~cm}^{-1}\right.$; 


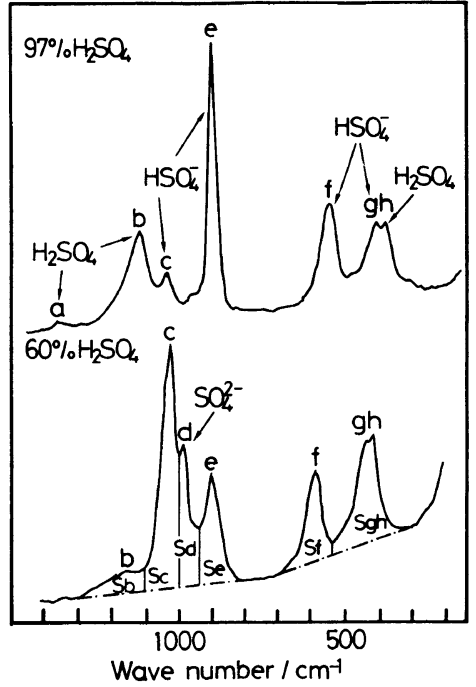

Figure 4. Typical Raman spectra of aq. $\mathrm{H}_{2} \mathrm{SO}_{4}$ solutions $\left(C_{\mathrm{sa}}=97 \mathrm{wt} \%\right.$ and $\left.60 \mathrm{wt} \%\right)$.

b, $1126-1180 \mathrm{~cm}^{-1}$; h, $\left.396-436 \mathrm{~cm}^{-1}\right)$, firstly dissociated $\mathrm{HSO}_{4}{ }^{-}$ion (c, $1032-1052 \mathrm{~cm}^{-1}$; e, $897-912 \mathrm{~cm}^{-1}$; f, $563-598 \mathrm{~cm}^{-1} ; \mathrm{g}, 424$ $\left.452 \mathrm{~cm}^{-1}\right)$ and secondarily dissociated $\mathrm{SO}_{4}{ }^{2-}$ ion $\left(\mathrm{d}, 974-998 \mathrm{~cm}^{-1}\right)$ are observed for aq. $\mathrm{H}_{2} \mathrm{SO}_{4}$ solution. Assignments shown in the figure are cited from the literature. ${ }^{25}$ The concentration of aq. $\mathrm{H}_{2} \mathrm{SO}_{4}$ with unknown $C_{\text {sa }}$ can be estimated by intensity ratio of peaks concerned with help of a calibration curve for $I_{\mathrm{k}}-C_{\mathrm{sa}}$ relation. Here, $I_{\mathrm{k}}$ is a peak intensity fraction for peak $k$ against total peak intensity (peak area) of all peaks, as defined below:

$$
I_{\mathrm{k}}=S_{\mathrm{k}} / \Sigma S_{\mathrm{k}}
$$

where $S_{\mathbf{k}}$ is a peak intensity (peak area; see Figure 4 for base line setting) of peak $k$ $(\mathrm{k}=\mathrm{a}-\mathrm{i})$.

Figure 5 illustrates some calibration curves for peaks b, c, and d. From this figure, aq. $\mathrm{H}_{2} \mathrm{SO}_{4}$ solutions can be divided into three categories according to $C_{\mathrm{sa}}$ (or dissociation state of $\mathrm{H}_{2} \mathrm{SO}_{4}$ ): Region I, $C_{\mathrm{sa}}=100-80 \mathrm{wt} \%$ where undissociated $\mathrm{H}_{2} \mathrm{SO}_{4}$ abruptly diminished and contrarily $\mathrm{HSO}_{4}{ }^{-}$ion steeply increases but without any existence of $\mathrm{SO}_{4}{ }^{2-}$

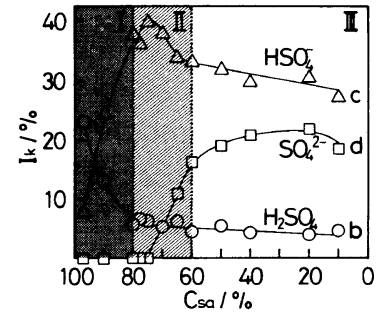

Figure 5. Caliburation curves (Plot of the peak intensity fraction $I_{\mathrm{k}} v s . C_{\mathrm{sa}}$ ) for typical peaks: $\mathrm{O}, \mathrm{b}$ (non-dissociated $\left.\mathrm{H}_{2} \mathrm{SO}_{4}\right) ; \triangle, \mathrm{c}\left(\mathrm{HSO}_{4}{ }^{-}\right) ; \square, \mathrm{d}\left(\mathrm{SO}_{4}{ }^{2-}\right)$.

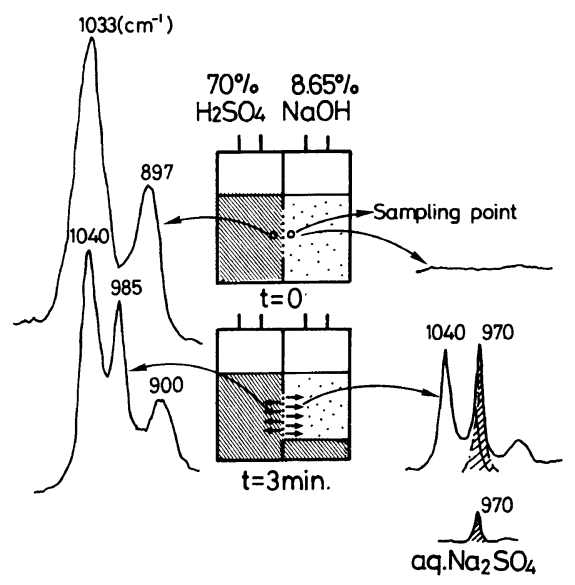

Figure 6. An illustration for material transportation between aq. $\mathrm{H}_{2} \mathrm{SO}_{4}$ solution with $C_{\mathrm{sa}}=70 \mathrm{wt} \%$ and $8.65 \mathrm{wt} \%$ aq. $\mathrm{NaOH}$ solution with Raman spectra (contact time $t=0,3 \mathrm{~min}$ ).

ion; Region II, $C_{\mathrm{sa}}=80-60 \mathrm{wt} \%$ where $\mathrm{HSO}_{4}{ }^{-}$ion and $\mathrm{SO}_{4}{ }^{2-}$ ion rapidly approaching their equilibrium states; Region III, $C_{\mathrm{sa}}=$ $40-0 \mathrm{wt} \%$ where $\mathrm{HSO}_{4}{ }^{-}$and $\mathrm{SO}_{4}{ }^{2-}$ ions are in the almost equilibrium state. Note that formation of $\mathrm{HSO}_{4}{ }^{-}$ion at $C_{\mathrm{sa}}=97-80 \mathrm{wt} \%$ and that of $\mathrm{SO}_{4}{ }^{2-}$ at $C_{\mathrm{sa}}=75-40 \mathrm{wt} \%$ take place independently owing to the large difference in their dissociation constant $K_{1}$ and $K_{2}\left(\mathrm{H}_{2} \mathrm{SO}_{4} \rightarrow \mathrm{H}^{+}+\mathrm{HSO}_{4}{ }^{-}, K_{1}=2000\right.$; $\left.\mathrm{HSO}_{4}{ }^{-} \rightarrow \mathrm{H}^{+}+\mathrm{SO}_{4}{ }^{2-}, K_{2}=0.02\right) .{ }^{26}$ Thus, when aq. $\mathrm{H}_{2} \mathrm{SO}_{4}$ solutions are employed as coagulant, their coagulation ability should be considered in view of their dissociation state.

Figure 6 illustrates material transportation between aq. $\mathrm{H}_{2} \mathrm{SO}_{4}$ solution with $C_{\mathrm{sa}}=70 \mathrm{wt} \%$ 
and $8.65 \mathrm{wt} \%$ aq. $\mathrm{NaOH}$ solution separated by a Teflon membrane, with showing Raman spectra. $\mathrm{SO}_{4}{ }^{2-}$ ion was already produced in aq. $\mathrm{H}_{2} \mathrm{SO}_{4}$ solution side 3 min after the contact of both solutions, exhibiting a characteristic peak at $985 \mathrm{~cm}^{-1}$. From the peak intensity analysis the sampled solution proved to correspond to an aq. $\mathrm{H}_{2} \mathrm{SO}_{4}$ with $C_{\mathrm{sa}}=40-50 \mathrm{wt} \%$. The transportation of $\mathrm{NaOH}$ into $\mathrm{H}_{2} \mathrm{SO}_{4}$ solution side is negligible and this conclusion might be reasonable because the solubility of $\mathrm{Na}_{2} \mathrm{SO}_{4}$ to $70 \mathrm{wt} \%$ aq. $\mathrm{H}_{2} \mathrm{SO}_{4}$ solution is as low as less than $3 \%$. On the other hand, the interfacial boundary along the Teflon membrane in aq. $\mathrm{NaOH}$ solution side, proved to consist of $50-60 \mathrm{wt} \%$ aq. $\mathrm{H}_{2} \mathrm{SO}_{4}$ and $\mathrm{Na}_{2} \mathrm{SO}_{4}$. Further, the bottom layer in aq. $\mathrm{NaOH}$ solution side was occupied by concentrated $\mathrm{H}_{2} \mathrm{SO}_{4}$. These facts lead to a conclusion that concentrated $\mathrm{H}_{2} \mathrm{SO}_{4}$ solution penetrates to aq. $\mathrm{NaOH}$ solution and the amount of $\mathrm{H}_{2} \mathrm{SO}_{4}$ is far larger than the expected for neutralization, and that aq. $\mathrm{H}_{2} \mathrm{SO}_{4}$ with $C_{\mathrm{sa}}=70 \mathrm{wt} \%$ allows only water from aq. $\mathrm{NaOH}$ solution to penetrate, that is, the $\mathrm{H}_{2} \mathrm{SO}_{4}$ solution exhibits a strong dehydration action.

Figure 7 shows the Raman peak intensity fraction $I_{\mathrm{k}}$ of interfacial boundary part in aq. $\mathrm{H}_{2} \mathrm{SO}_{4}$ solution side as a function of contact time when cellulose $/ 8.65 \mathrm{wt} \%$ aq. $\mathrm{NaOH}$ systems (A, Cell-I system; B, Cell-II system) was contacted through Teflon membrane. At the final stage of contact a similar tendency that $\mathrm{HSO}_{4}{ }^{-}$ion diminishes slowly with an increase of $\mathrm{SO}_{4}{ }^{2-}$ ion was observed for both systems. However, at initial stage of contact, the rapid decrease of $\mathrm{HSO}_{4}{ }^{-}$ion and the increase of $\mathrm{SO}_{4}{ }^{2-}$ ion occurred at an instance of contact for Cell-II system while these changes were relatively gradual for Cell-I system. As seen in Figure 5, aq. $\mathrm{H}_{2} \mathrm{SO}_{4}$ having strong ability to give a densely coagulated state to the cellulose films exists in Region II, and these $\mathrm{H}_{2} \mathrm{SO}_{4}$ solutions are in a transition state to easily produce $\mathrm{SO}_{4}{ }^{2-}$ ion by absorbing water from other media. Of these $\mathrm{H}_{2} \mathrm{SO}_{4}$

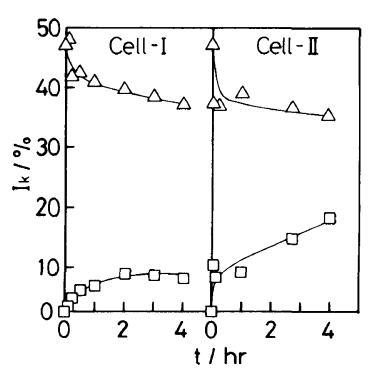

Figure 7. Plot of the Raman peak intensity fraction $I_{k}$ of interfacial boundary part in aq. $\mathrm{H}_{2} \mathrm{SO}_{4}$ solution side as a function of contact time when cellulose $/ 8.65 \mathrm{wt} \%$ aq. $\mathrm{NaOH}$ systems was contacted through Teflon membrane: Symbols are the same shown in Figure 5.

solutions aq. $\mathrm{H}_{2} \mathrm{SO}_{4}$ with $C_{\mathrm{sa}} \geqq 70 \mathrm{wt} \%$ is capable of strongly dissolving cellulose and facilitating decomposition of cellulose, as Bartunek $^{27}$ and Turbak et al. ${ }^{19}$ pointed out, if dehydration action of the $\mathrm{H}_{2} \mathrm{SO}_{4}$ solution does not work well.

Figure 8 shows $\mathrm{CP} / \mathrm{MAS}{ }^{13} \mathrm{C}$ NMR spectra of the cellulose films used in Figure 2 (A, Cell-I films; B, Cell-II films). The spectra were recorded both in dry and wet state and $\chi_{\mathrm{am}}\left(\mathrm{C}_{3}\right)$ values, which means an extent of break-down of intramolecular hydrogen bond, such as $\mathrm{C}_{3}-\mathrm{OH} \cdots \mathrm{O}_{5}{ }^{\prime}{ }^{4}$ are also shown in the figure. Obviously, the patterns of NMR spectra for Cell-I films at dry state abruptly changed at $C_{\text {sa }}=50-60 \mathrm{wt} \%$, revealing a sudden increase in $\chi_{\mathrm{am}}\left(\mathrm{C}_{3}\right)$ value, and corresponding changes were observed at $C_{\mathrm{sa}}=60-65 \mathrm{wt} \%$ for Cell-II films. This means that the formation of intramolecular hydrogen bond at $\mathrm{C}_{3}$ position becomes hard beyond the threshold value of $C_{\mathrm{sa}}(60 \mathrm{wt} \%$ for Cell-I system, $65 \mathrm{wt} \%$ for Cell-II system) of aq. $\mathrm{H}_{2} \mathrm{SO}_{4}$ used as coagulant.

The NMR spectra at wet state and the value of $\chi_{a m}\left(C_{3}\right)$ wet $/ \chi_{a m}\left(C_{3}\right)$ dry clearly point a critical $C_{\mathrm{sa}}$ value ( $=65 \mathrm{wt} \%$ ) for both systems, beyond which $\chi_{\mathrm{am}}\left(\mathrm{C}_{3}\right)$ wet $/ \chi_{\mathrm{am}}\left(\mathrm{C}_{3}\right)$ dry becomes almost unity and appearance of sharp peaks in $\mathrm{C}_{4}$ carbon peak region by wetting is strongly depressed. The result is clearly pictured in Figure 9. These results indicate that aq. $\mathrm{H}_{2} \mathrm{SO}_{4}$ solution having an ability to 
(A)

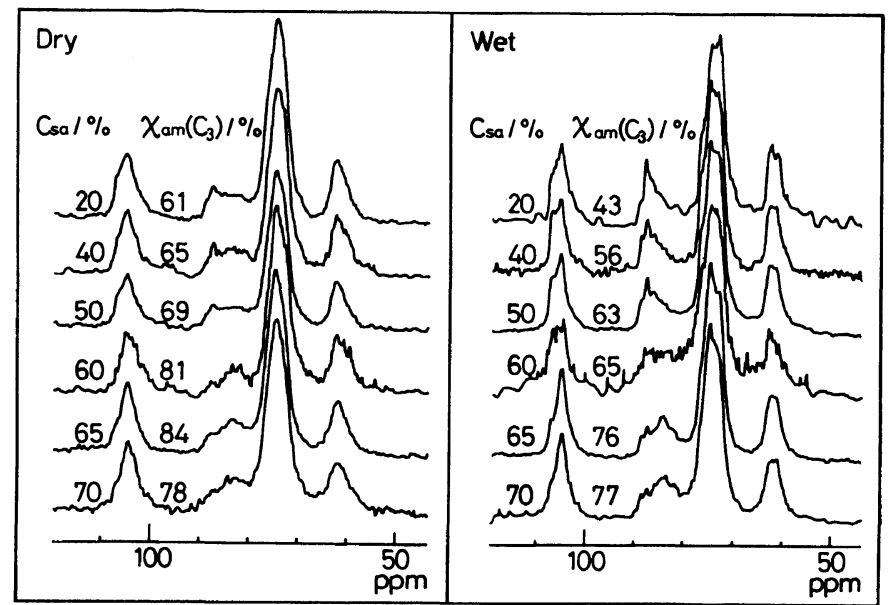

(B)

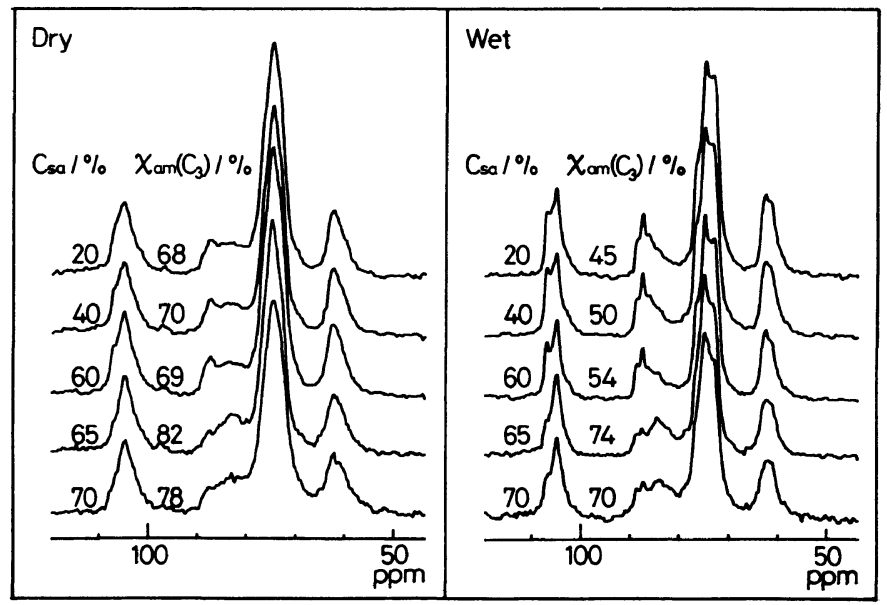

Figure 8. CP/MAS ${ }^{13} \mathrm{C}$ NMR spectra of the cellulose films used in Figure 2: A, Cell-I films; B, Cell-II films. $\chi_{a m}\left(C_{3}\right)$ values are also shown in the figure.

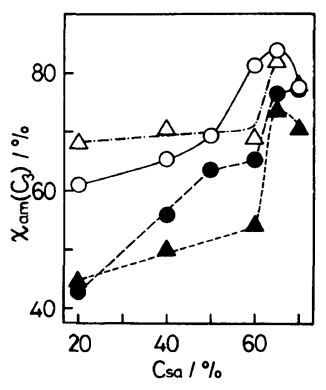

Figure 9. $\chi_{\mathrm{am}}\left(\mathrm{C}_{3}\right)$ dry and $\chi_{\mathrm{am}}\left(\mathrm{C}_{3}\right)$ wet of the cellulose films as a function of concentration of coagulants $C_{\mathrm{sa}}$ : $\bigcirc$, Cell-I (dry); $\bigcirc$, Cell-I (wet); $\triangle$, Cell-II (dry); $\boldsymbol{\Delta}$, Cell-II (wet). coagulate cellulose film densely is also able to produce the structure in which cellulose molecules are not mobile when wet, ${ }^{28-30}$ although the development of $\mathrm{C}_{3}-\mathrm{OH} \cdots \mathrm{O}_{5}{ }^{\prime}$ intramolecular hydrogen bond formation is quite low.

Influence of Cellulose Concentration $C_{\mathrm{P}}$ on the Coagulation State of Lyophilized Cellulose Films

Figure 10 shows SEM micrographs of the lyophilized films prepared from cellulose solutions with various $C_{\mathrm{P}}$ using aq. $\mathrm{H}_{2} \mathrm{SO}_{4}$ 
(a)

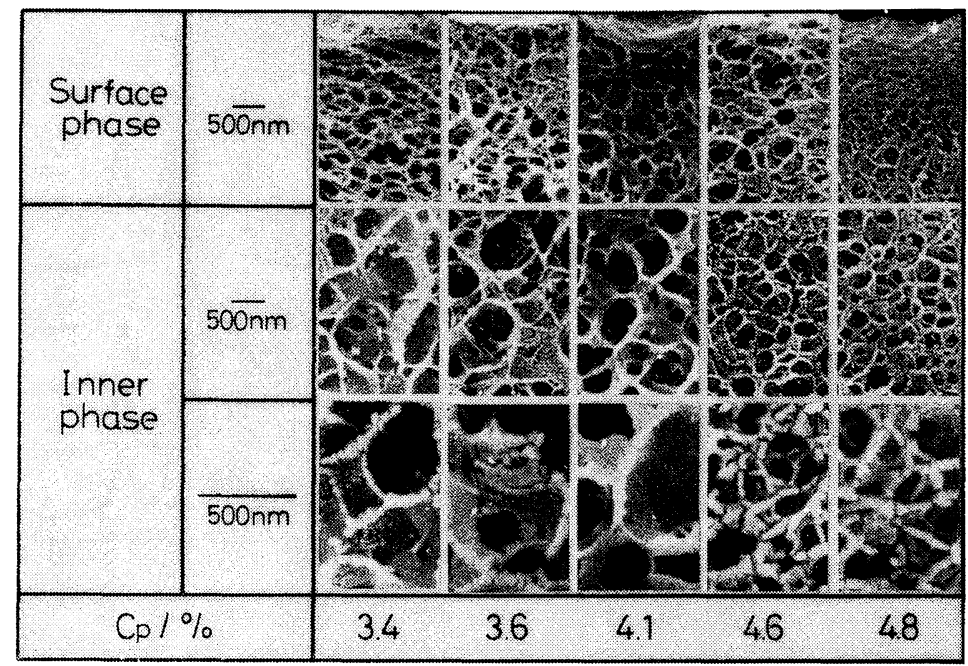

(b)

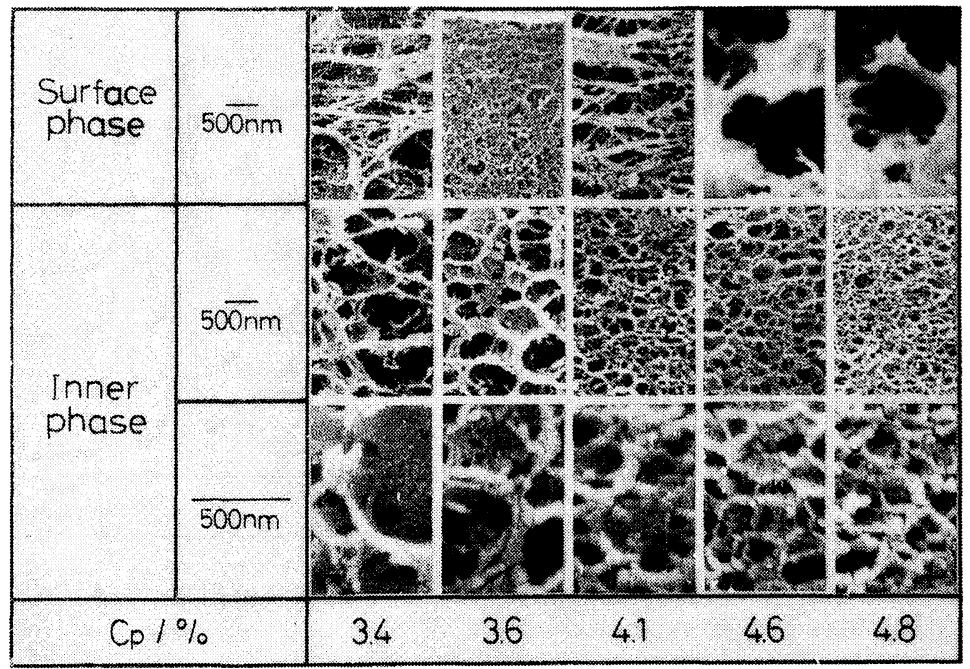

(A)

(Figure 10. (A))

solutions at $5^{\circ} \mathrm{C}$ for $5 \mathrm{~min}$. For Cell-I system, $C_{\mathrm{P}}$ ranges from 3.4 to $4.8 \mathrm{wt} \%$ and two aq. $\mathrm{H}_{2} \mathrm{SO}_{4}$ solutions with $C_{\mathrm{sa}}=20$ and $70 \mathrm{wt} \%$ were used as coagulants. For Cell-II system, $C_{\mathrm{P}}$ range of $3.8-5.6 \mathrm{wt} \%$ and two coagulants with $C_{\mathrm{sa}}=20$ and $60 \mathrm{wt} \%$ were adopted. Aq. $\mathrm{H}_{2} \mathrm{SO}_{4}$ with $C_{\mathrm{sa}}=20 \mathrm{wt} \%$ did not give skin structure for both systems, irrespective of $C_{\mathrm{p}}$. Average pore size $(2 r)$ of the inner phase of films became smaller $(1000 \mathrm{~nm} \rightarrow 200 \mathrm{~nm}$ for Cell-I film; $400 \mathrm{~nm} \rightarrow 200 \mathrm{~nm}$ for Cell-II film) for both systems with an increase in $C_{\mathrm{P}}$ and $2 r$ of Cell-II film was smaller than that of Cell-I film, if the $C_{\mathrm{P}}$ is constant. When aq. $\mathrm{H}_{2} \mathrm{SO}_{4}$ solution with higher $C_{\mathrm{sa}}$ is employed as coagulant the average pore size $(2 r)$ of the inner phase of Cell-I films became smaller $(300 \mathrm{~nm}$ for $C_{\mathrm{sa}}=20 \%, 200 \mathrm{~nm}$ for $C_{\mathrm{sa}}=70 \%$ at $\left.C_{\mathrm{P}}=4.8 \%\right)$ and the UP $+\mathrm{M}$ structure of Cell-I film changed to UP structure at $C_{\mathrm{P}} \geqq 4.1 \mathrm{wt} \%$. The surface of the Cell-I films, however, became more porous with an increase in $C_{\mathrm{P}}$ owing 
(a)

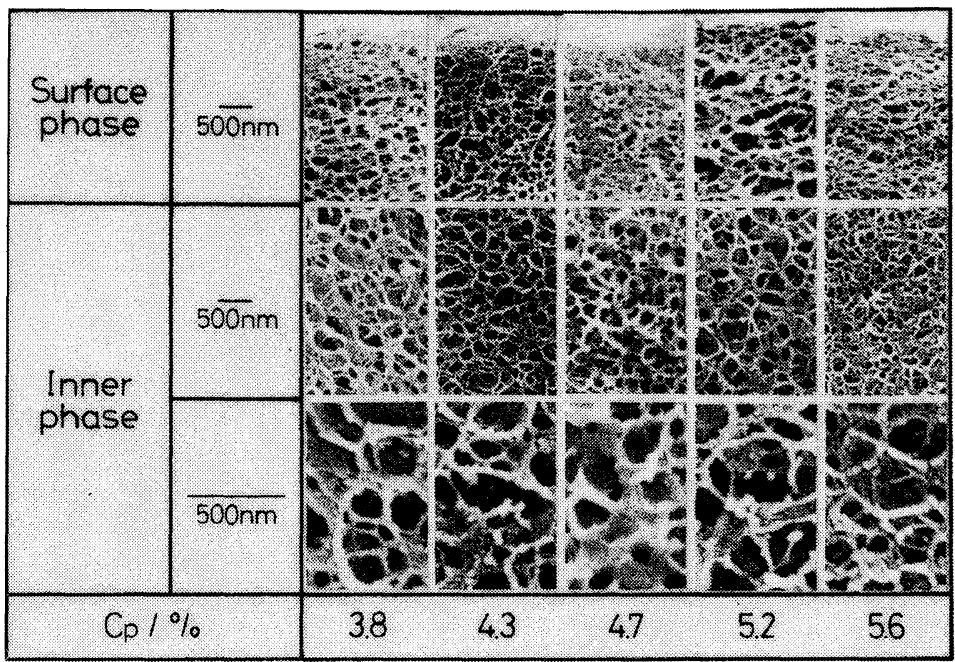

(b)

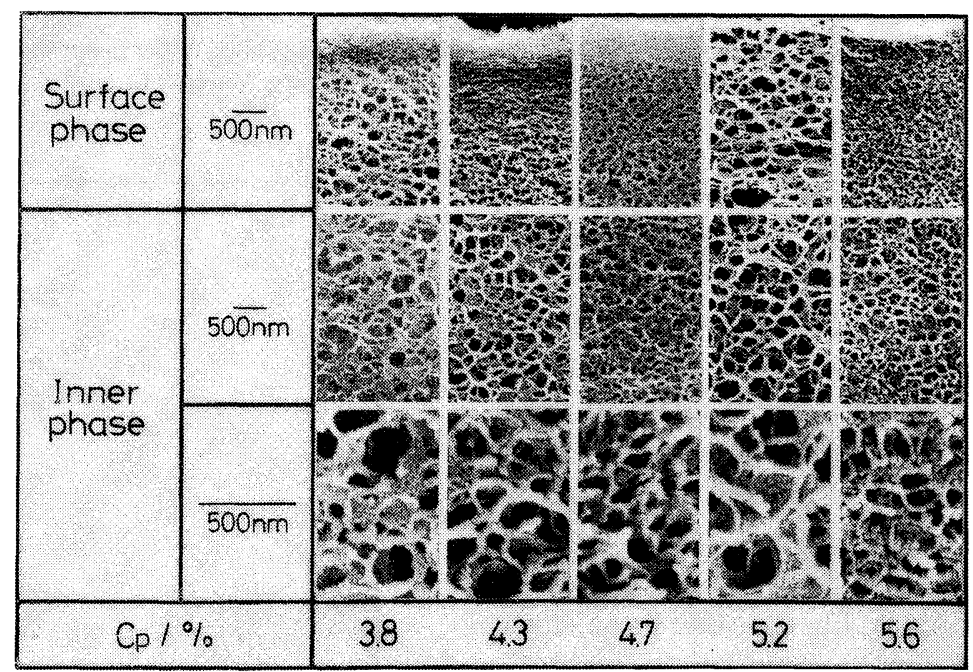

(B)

(Figure 10. (B))

Figure 10. SEM micrographs of the lyophilized films prepared from cellulose solutions with various cellulose concentration $C_{\mathrm{P}}$ using aq. $\mathrm{H}_{2} \mathrm{SO}_{4}$ solutions at $5^{\circ} \mathrm{C}$ for $5 \mathrm{~min}$ : A, Cell-I films $\left(\mathrm{a}, C_{\mathrm{sa}}=20 \mathrm{wt} \%\right.$; $\left.\mathrm{b}, C_{\mathrm{sa}}=70 \mathrm{wt} \%\right)$; B, Cell-II films (a, $C_{\mathrm{sa}}=20 \mathrm{wt} \%$; b, $\left.C_{\mathrm{sa}}=60 \mathrm{wt} \%\right)$.

to strong dissolving ability of aq. $\mathrm{H}_{2} \mathrm{SO}_{4}$ with higher $C_{\mathrm{sa}}$. This might be reasoned by the fact that Cell-I system with low $C_{\mathrm{p}}$ has larger content of alkali by which concentrated $\mathrm{H}_{2} \mathrm{SO}_{4}$ is neutralized, leading to the restriction of dissolving action of the acid against cellulose film produced. Aq. $\mathrm{H}_{2} \mathrm{SO}_{4}$ with high $C_{\text {sa }}$ gave a skin structure to Cell-II films, irrespective of $C_{\mathrm{P}}$. The pore size of the inner phase of Cell-II films became smaller $(300 \mathrm{~nm} \rightarrow 200 \mathrm{~nm})$ with an increase in $C_{\mathrm{P}}$, but the size of secondary particles kept almost constant $\left(d_{\mathrm{P}}=c a .30 \mathrm{~nm}\right)$.

\section{Influence of Coagulation Time on the Coagula- tion State of the Films}

Figure 11 shows SEM micrographs of the lyophilized cellulose films coagulated under given conditions (Cell-I: $C_{\mathrm{P}}=4.1 \mathrm{wt} \%, C_{\mathrm{sa}}=65$ 


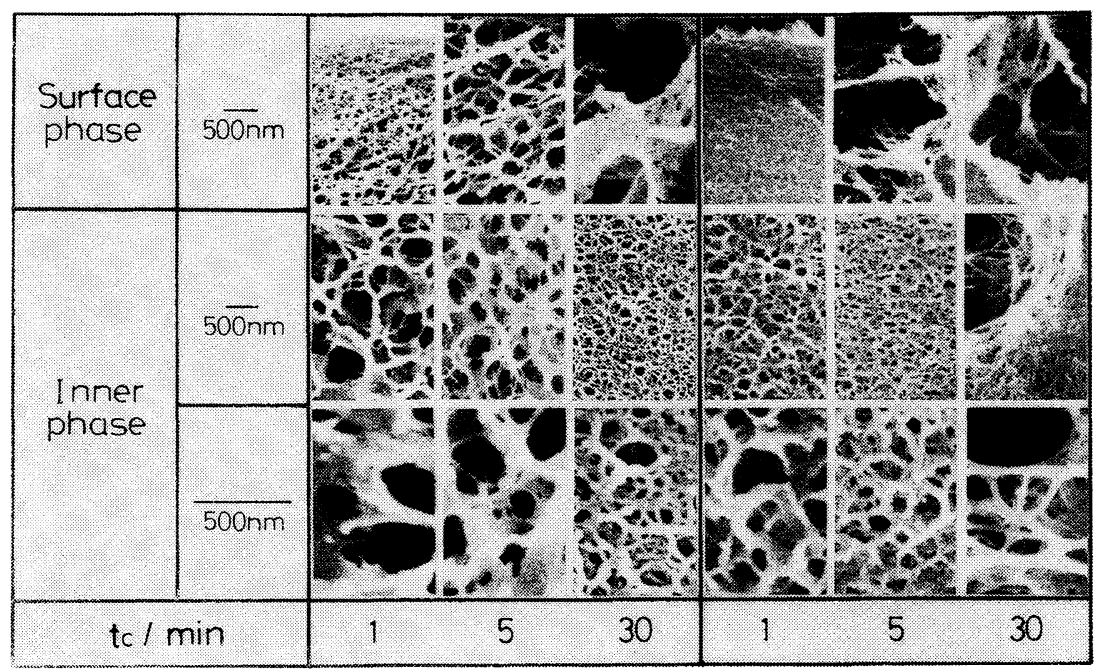

(A)

(B)

Figure 11. SEM micrographs of the lyophilized cellulose films coagulated under given conditions (Cell-I, $C_{\mathrm{P}}=4.1 \mathrm{wt} \%, C_{\mathrm{sa}}=65 \mathrm{wt} \%$; Cell-II, $\left.C_{\mathrm{P}}=4.7 \mathrm{wt} \%, C_{\mathrm{sa}}=65 \mathrm{wt} \%\right)$ as a function of coagulation time $t_{\mathrm{c}}: \mathrm{A}$, Cell-I films; B, Cell-II films.

wt $\%$; Cell-II: $C_{\mathrm{P}}=4.7 \mathrm{wt} \%, C_{\mathrm{sa}}=65 \mathrm{wt} \%, 5^{\circ} \mathrm{C}$ ) as a function of coagulation time $t_{\mathrm{c}}$. For both films, longer $t_{\mathrm{c}}$ resulted in the films with somewhat porous surface. Obviously Cell-II films exhibited similar and most dense coagulation state both for surface and inner phase concurrently at $t_{\mathrm{c}}=1 \mathrm{~min}$, with skin structure (thickness, $c a$. $5 \mu \mathrm{m}$ ). This results well correspond to the result shown in Figure 7 where material tarnsportation was pictured by Raman spectroscopy. On the other hand, it was difficult to find out the coagulation conditions for Cell-I films to give similar and most dense coagulation state both for surface and inner phase concurrently. In a separate experiment using aq. $\mathrm{H}_{2} \mathrm{SO}_{4}$ with $C_{\mathrm{sa}}=20 \mathrm{wt} \%$ the followings were clarified: (1) The pore size of the inner phase of Cell-I films was almost constant $(\mathrm{ca} .400 \mathrm{~nm})$ at $t_{\mathrm{c}} \geqq 7 \mathrm{~min}$ and similarily the pore size of the surface was constant $(300 \mathrm{~nm})$ at $t_{\mathrm{c}} \geqq 5 \mathrm{~min},(2)$ The surface of Cell-II films became most dense $(2 r=c a .100 \mathrm{~nm})$ at $t_{\mathrm{c}} \geqq 5 \mathrm{~min}$ and the pore size of inner phase kept constant $(2 r=c a$. $200 \mathrm{~nm})$, irrespective of $t_{\mathrm{c}}$.

Figure 12 shows the diffused distance $L$ of aq. $\mathrm{H}_{2} \mathrm{SO}_{4}$ phase into cellulose/aq. $\mathrm{NaOH}$

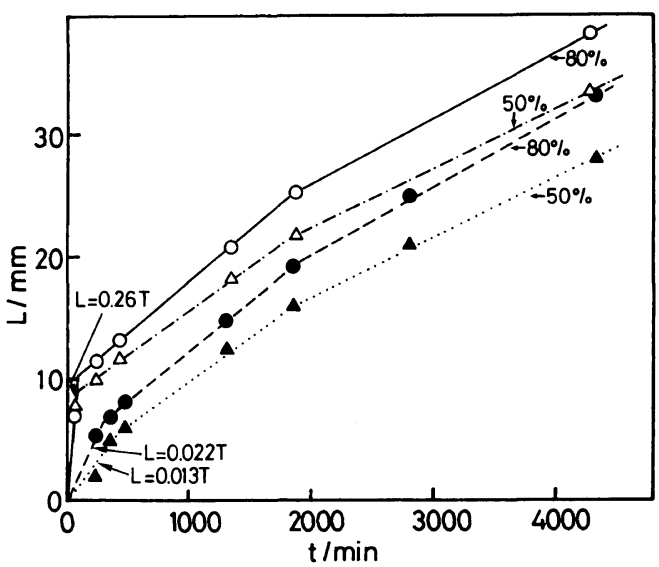

Figure 12. Plot of diffused distance $L$ of aq. $\mathrm{H}_{2} \mathrm{SO}_{4}$ phase into cellulose/aq. $\mathrm{NaOH}$ systems $\left(C_{\mathbf{P}}=5 \mathrm{wt} \%\right)$ : $\bigcirc$, Cell-I system with $C_{\mathrm{sa}}=80 \mathrm{wt} \% ; \triangle$, Cell-I system with $C_{\mathrm{sa}}=50 \mathrm{wt} \%$; Cell-I system with $C_{\mathrm{sa}}=80 \mathrm{wt} \%$; Cell-I system with $C_{\mathrm{sa}}=50 \mathrm{wt} \%$.

systems $\left(C_{\mathrm{P}}=5 \mathrm{wt} \%\right)$ when the cellulose solution is placed gently on aq. $\mathrm{H}_{2} \mathrm{SO}_{4}$ solutions with $C_{\mathrm{sa}}=50$ and $80 \mathrm{wt} \%$. Aq. $\mathrm{H}_{2} \mathrm{SO}_{4}$ solution with higher $C_{\mathrm{sa}}$ diffused faster into the cellulose solution than aq. $\mathrm{H}_{2} \mathrm{SO}_{4}$ with lower $C_{\mathrm{sa}}$. The diffusion rate of aq. $\mathrm{H}_{2} \mathrm{SO}_{4}$ is clearly far larger for Cell-II system than for Cell-I system. These phenomena also coinside with 
the result shown in Figures 7 and 11. In the case where aq. $\mathrm{H}_{2} \mathrm{SO}_{4}$ with $C_{\mathrm{sa}}=80 \mathrm{wt} \%$ is used, the diffusion rate at initial stage is estimated as $0.37 \mu \mathrm{m} \mathrm{s}^{-1}$ for Cell-I system and $4.3 \mu \mathrm{m} \mathrm{s}^{-1}$ for Cell-II system. The time required for complete diffusion of aq. $\mathrm{H}_{2} \mathrm{SO}_{4}$ from the surface to bottom of the cast cellulose solution with thickness with $1 \mathrm{~mm}$ is estimated as $45 \mathrm{~min}$ for Cell-I system and $4 \mathrm{~min}$ for Cell-II system. The estimated values well correspond to $t_{\mathrm{c}}$ for obtaining most dense coagulation state of inner phase of the films shown in Figure 11.

\section{Influence of Coagulation Temperature on the Coagulation State of the Films}

Figure 13 shows SEM micrographs of the lyophilized cellulose films coagulated under given conditions (Cell-I; $C_{\mathrm{P}}=4.1 \mathrm{wt} \%, C_{\mathrm{sa}}=$ $65 \mathrm{wt} \%$; Cell-II, $C_{\mathrm{P}}=4.7 \mathrm{wt} \%, C_{\mathrm{sa}}=65 \mathrm{wt} \%$, $5 \mathrm{~min})$ as a function of coagulation temperature $T_{\mathrm{c}}\left(-6-40^{\circ} \mathrm{C}\right)$. For both films, $T_{\mathrm{c}}=5^{\circ} \mathrm{C}$ resulted in the most dense inner phase (Cell-I,

(A)

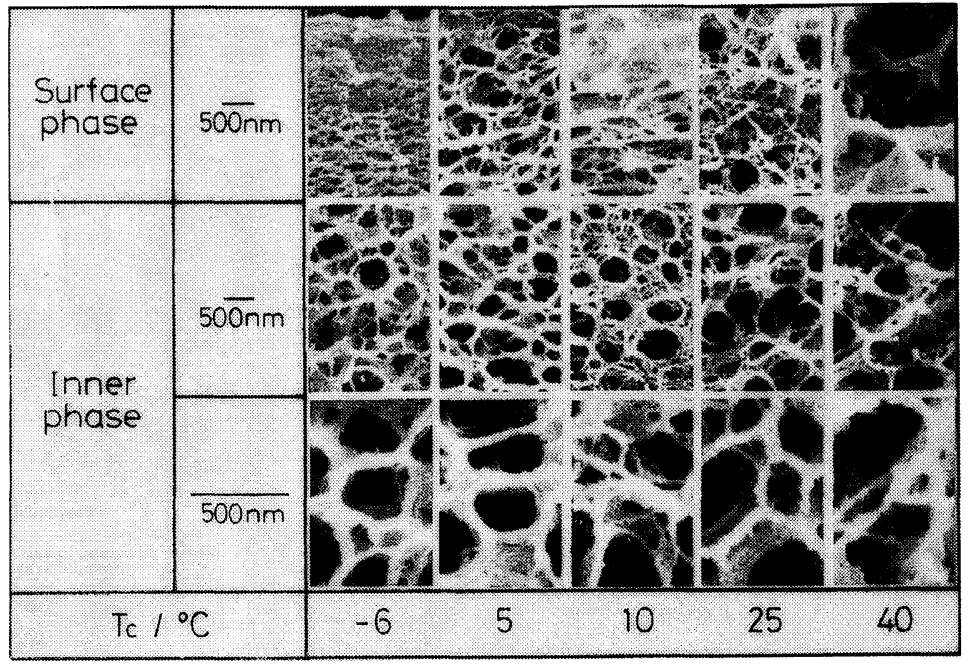

(B)

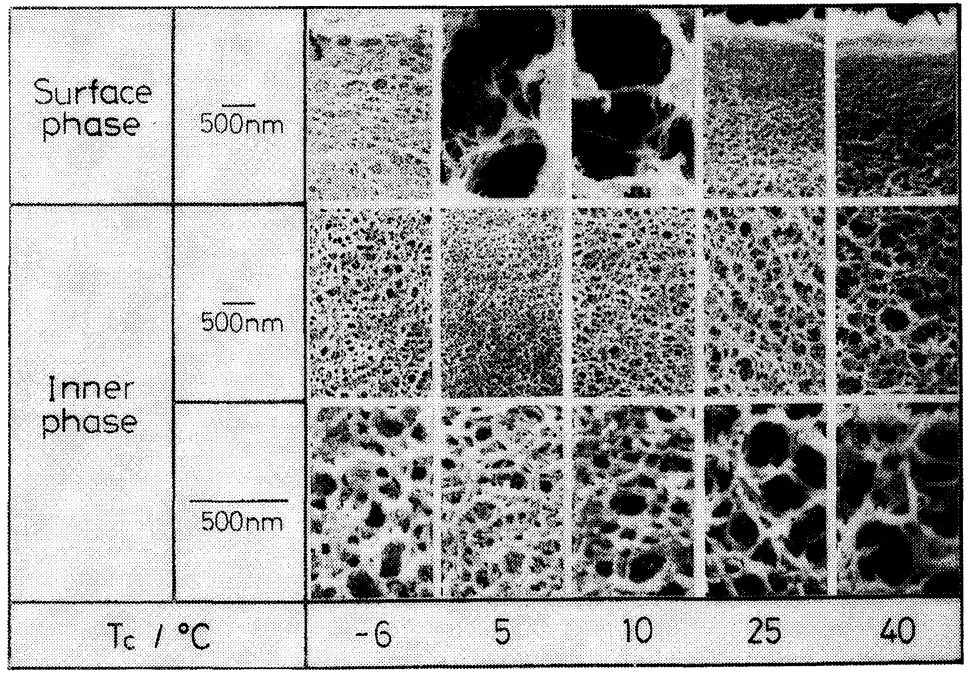

Figure 13. SEM micrographs of the lyophilized cellulose films coagulated under given conditions (Cell-I, $C_{\mathrm{P}}=4.1 \mathrm{wt} \%, C_{\mathrm{sa}}=65 \mathrm{wt} \%$; Cell-II, $C_{\mathrm{P}}=4.7 \mathrm{wt} \%, C_{\mathrm{sa}}=65 \mathrm{wt} \%$ ) as a function of coagulation temperature $T_{\mathrm{c}}\left(-6-40^{\circ} \mathrm{C}\right)$ : A, Cell-I films; B, Cell-II films. 
$2 r=c a .500 \mathrm{~nm}$; Cell-II, $2 r=50 \mathrm{~nm}$ ). Obviously the surface of Cell-I film exhibited porous structure at higher $T_{\mathrm{c}}$ while the porous structure of the surface was observed at lower $T_{\mathrm{c}}$ for Cell-II films. This might correspond to the dissolving action of the coagulant at lower $T_{\mathrm{c}}$ for Cell-II film and to the decomposing action of the coagulant at higher $T_{\mathrm{c}}$ for Cell-I film.

Figures 14 and 15 summarize the relation between average pore size $(2 r)$ of the surface $\left(A_{1}, B_{1}\right)$ and inner phase $\left(A_{2}, B_{2}\right)$ of the coagulated films and coagulation conditions. In the former figure the average pore size $(2 r)$ of the films is shown by circle on a three dimensional coordinate ( $x$ axis, $t_{\mathrm{c}} ; y$ axis, $C_{\mathrm{sa}}$; $z$ axis, $\left.T_{\mathrm{c}}\right)$. In the latter figure $2 r$ of the films is plotted on a two dimensional coodinate when one of coagulation condition is kept constant. Note that the size of circle is shown in the figure according to the real pore size. Symbol+ means that at the conditions the estimation of pore size was impossible. As was mentioned
(A)

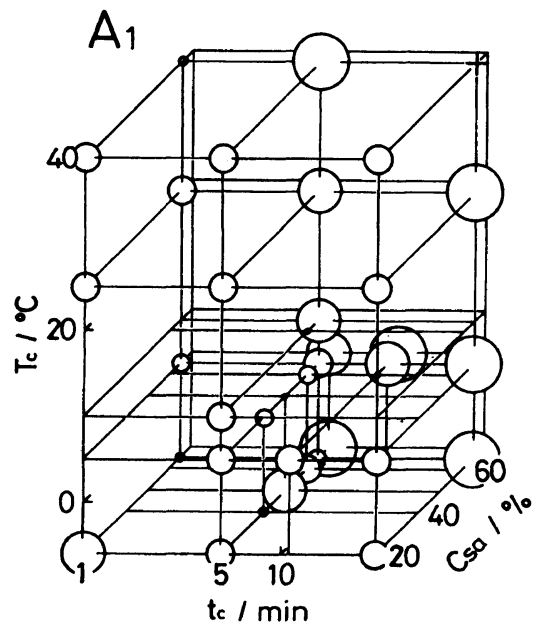

(B)

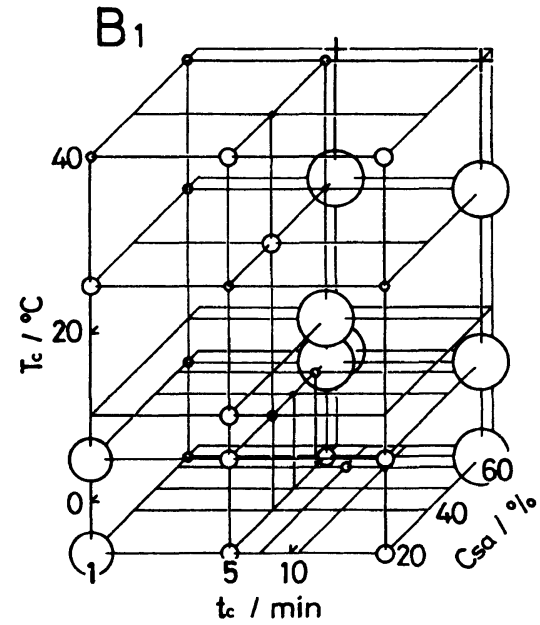

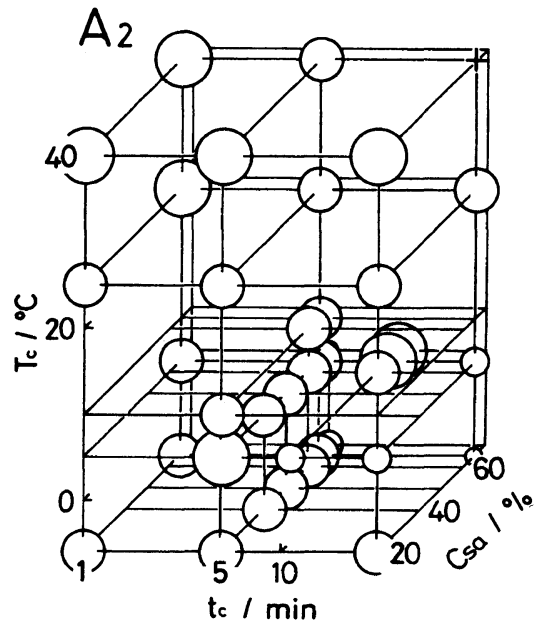

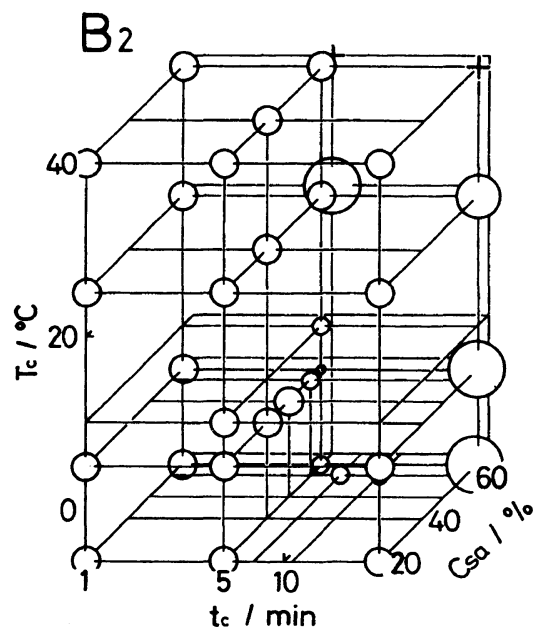

Figure 14. Relation between average pore size $(2 r)$ of the surface $\left(A_{1}, B_{1}\right)$ and inner phase $\left(A_{2}, B_{2}\right)$ of the coagulated films and coagulation conditions $\left(x\right.$ axis, coagulation time $t_{\mathrm{c}} ; y$ axis, sulfuric acid concentration $C_{\mathrm{sa}} ; z$ axis, coagulation tempetature $T_{\mathrm{c}}$ ): A, Cell-I film; B, Cell-II film. The size of circle is shown in the figure according to real pore size. Symbol + means that at the conditions the estimation of pore sized was immposible. 
(A)

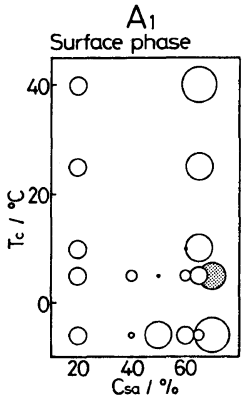

(B)

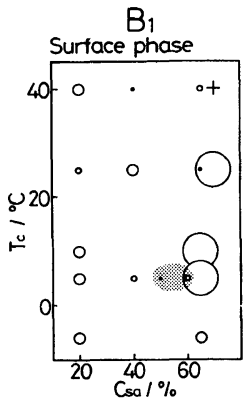

$\mathrm{A}_{2}$
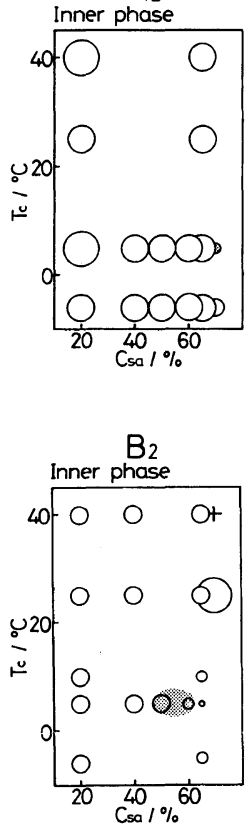

previously in this paper, Cell-II films tend to take more dense structure than Cell-I films and the surface of films is generally more dense than the inner phase. Cell-II films have several coagulation conditions under which clear skin structure was formed and both surface and inner phase were concurrently coagulated in quite dense manner, different from Cell-I films. The phenomenological difference observed for Cell-I and Cell-II films by coagulation are summarized in Table I.

\section{CONCLUSION}

An attempt was made to clarify the structure and morphology of the cellulose films coagulated from novel cellulose $/ 9 \mathrm{wt} \%$ aqueous (aq.) sodium hydroxide $(\mathrm{NaOH})$ systems (polymer concentration $C_{\mathrm{P}} \leqq 5.6 \mathrm{wt} \%$ ) by using aq. sulfuric acid $\left(\mathrm{H}_{2} \mathrm{SO}_{4}\right)$ with various concentration $\left(C_{\mathrm{sa}}=20-80 \mathrm{wt} \%\right)$ as coagulants. For this purpose two types of alkali-soluble celluloses with either crystal form of cellulose-I (Cell-I, steam exploded spruce pulp) or cellulose-II (Cell-II, regenerated from cotton/cuprammo-

Figure 15. Relation between particle size $\left(d_{\mathrm{p}}\right)$ of the surface $\left(A_{1}, B_{1}\right)$ and inner phase $\left(A_{2}, B_{2}\right)$ of the coagulated films and coagulation conditions under constant $t_{\mathrm{c}}$ or constant $C_{\mathrm{sa}}$ : A, Cell-I films; B, Cell-II films. Symbols have same meaning as shown in Figure 14.

Table I. Phenomenological difference in coagulated state of celluloses obtained from Cell-I/NaOH, Cell-II/ $/ \mathrm{NaOH}$ systems under acid coagulation conditions

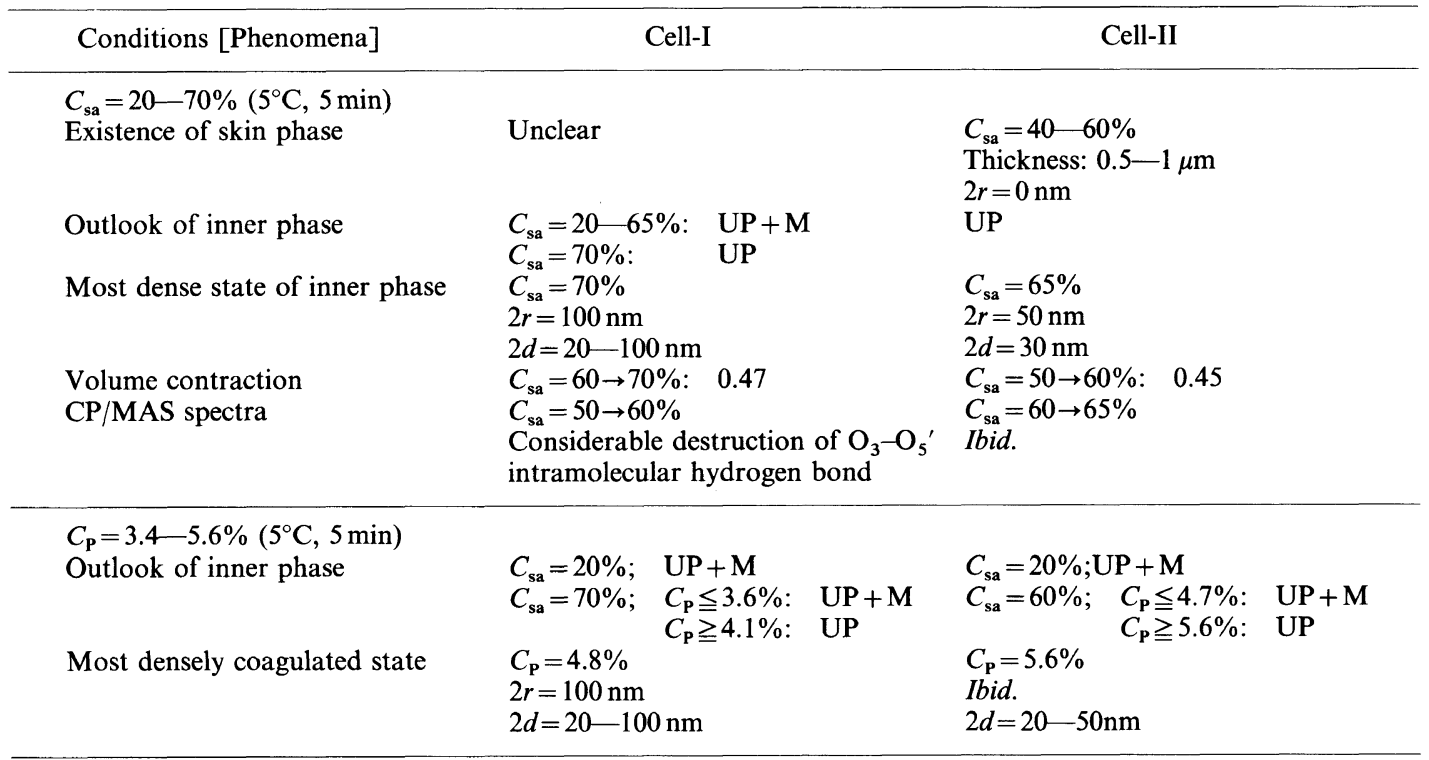


nium solution) were utilized. Several phenomenological differences were detected for Cell-I and Cell-II systems. SEM observation on the lyophilized coagulated cellulose films revealed the following difference: (1) For alkali-soluble Cell-II system, the existence of secondary particles was evident in the range of $C_{\text {sa }} \geqq 20$ $\mathrm{wt} \%$ and the most dense structure was given when $C_{\mathrm{sa}}=65 \mathrm{wt} \%$, (2) For alkali-soluble Cell-I system, the secondary particles became detectable at $C_{\mathrm{sa}} \geqq 65 \mathrm{wt} \%$ and the coagulant with $C_{\mathrm{sa}} \geqq 65-70 \mathrm{wt} \%$ gave the most dense structure of the film, and (3) the particle size constituting the most dense structure of the films is smaller for Cell-II system than Cell-I system. A strong dehydrating action from cellulose solutions was confirmed for the coagulant with $C_{\mathrm{sa}} \geqq 60 \mathrm{wt} \%$ by Raman spectroscopy and the neutralization rate of Cell-II system was much higher than Cell-I system. CP/MAS ${ }^{13} \mathrm{C}$ NMR analysis showed that both densely coagulated films developed practically no intramolecular hydrogen bond at $\mathrm{C}_{3}$ position.

\section{REFERENCES}

1. T. Yamashiki, T. Matsui, M. Saitoh, K. Okajima, K. Kamide, and T. Sawada, Br. Polym. J., 22, 73 (1990).

2. T. Yamashiki, T. Matsui, M. Saitoh, K. Okajima, K. Kamide, and T. Sawada, Br. Polym. J., 22, 121 (1990).

3. T. Yamashiki, T. Matsui, M. Saitoh, K. Okajima, K. Kamide, Y. Matsuda, and T. Sawada, Br. Polym. J., 22, 201 (1990).

4. K. Kamide, K. Okajima, T. Matsui, and K. Kowsaka, Polym. J., 16, 857 (1984).

5. K. Kowsaka, K. Okajima, and K. Kamide, Polym. J., 24, 71 (1992).

6. T. Yamashiki, K. Kamide, K. Okajima, K. Kowsaka, T. Matsui, and H. Fukase, Polym. J., 20, 447 (1988).

7. K. Kamide and M. Saito, Polym. J., 18, 569 (1986).

8. K. Kamide, M. Saito, and K. Kowsaka, Polym. J., 19, 1173 (1987).

9. K. Kamide, K. Yasuda, T. Matsui, K. Okajima, and T. Yamashiki, Cellulose Chem. Technol., 24, 23 (1990).

10. K. Kowsaka, H. Yamada, K. Okajima, and K. Kamide, to be submitted to Polym. International.

11. T. Yamashiki, T. Matsui, K. Kowsaka, M. Saitoh,
K. Okajima, and K. Kamide, J. Appl. Polym. Sci., in press.

12. T. Yamashiki, M. Saitoh, K. Yasuda, K. Okajima, and K. Kamide, Cellulose Chem. Technol., 24, 237 (1990).

13. H. Williams US Patent $3,236,669$ (1966).

14. C. Graenacher, and Sallman, US Patent $2,179,181$ (1939); D. Johnson, Br. Patent 1,144,048 (1969).

15. S. Hudson and J. Cuculo, J. Polym. Sci., Polym. Chem. Ed., 18, 3469 (1980).

16. D. Johnson, M. Nicolson, and F. Haigh, in "Proceeding of the Eighth Cellulose Conference," A. Turbak, Ed., Wiley-Interscience, New York, N.Y., 1976, p. 931.

17. K. Kamide, K. Okajima, T. Matsui, and S. Manabe, Polym. J., 12, 521 (1980).

18. A. Turbak, A. El-Kafrawy, F. Snyder, and A. Auerbach, US Patent 4,302,252 (1981).

19. For example, A. Turbak, ed., "Solvent Spun Rayon, Modified Cellulose Fibers and Derivatives," ACS series 58, Washington, D.C., 1977.

20. K. Kamide, in "Thermodynamics of Polymer Solutions. Phase Equilibria and Critical Phenomena," A. D. Jenkins, ed., Polymer Science Library 9, Elsevier, Amsterdam, 1990, Chapter 6.

21. K. Kamide, K. Yasuda, M. Saito, and K. Okajima, Polym. Prepr. Jpn., 38, 1126, (1989).

22. K. Kamide, M. Saito, and K. Yasuda, in "Viscoelasticity of Biomaterials," ACS Symposium Series, No. 489, W. G. Glasser and H. Hatakeyama, Ed., The American Chemical Society, Washington, D.C., 1992, Chapter 12.

23. K. Kamide and S. Manabe, "Role of Micro-Phase Separation Phenomena in the Formation of Porous Polymeric Membrane," ACS Symposium Series, No. 269, The American Chemical Society, Washington, D.C., 1985, p 197.

24. K. Kamide, S. Manabe, T. Matsui, T. Sakamoto, and S. Kajita, Kobunshi Ronbunshu, 34, 205 (1977).

25. R. J. Gillespie and E. A. Robinson, Can. J. Chem., 40, 664, 658, 675, 784 (1962); G. E. Walrafen, $J$. Chem. Phys., 40, 2236 (1964).

26. T. F. Young, L. F. Maranville, and H. M. Smith, "Structure of Electrolytic Solutions," W. J. Hammer, Ed., John Wiley \& Sons, New York, N.Y., p. 48 1959.

27. R. Bartunek, Das Papeir, 7, 153 (1953).

28. F. Horii, A. Hirai, and R. Kitamaru, Ann. Report Res. Inst. Chem. Fibers, Jpn, 42, 41 (1985).

29. F. Horii, A. Hirai, R. Kitamaru, and I. Sakurada, Cellulose Chem. Technol., 19, 513 (1985).

30. F. Horii, A. Hirai, and R. Kitamaru, in "The Structures of Cellulose. Characterization of the Solid States," ACS Symposium Series, No. 340, R. H. Atalla, Ed., The American Chemical Society, Washington, D.C., 1987, Chapter 6, p 119. 